\title{
FAKTOR KRIMINOGEN PENYALAHGUNAAN SENJATA TAJAM DI MUKA UMUM
}

\author{
Agus Nur Arsad \\ Universitas Suryakancana \\ E-Mail:agusnur.arsyad@yahoo.com
}

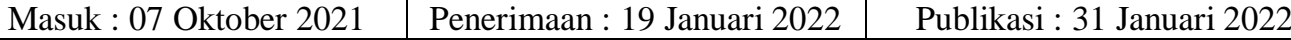

\begin{abstract}
ABSTRAK
Kejahatan yang terjadi di masyarakat merupakan sebuah pelanggaran terhadap hukum positif, yaitu hukum pidana. Penggunaan senjata tajam secara umum sering digunakan dalam aksi tawuran yang dilakukan baik dalam tingkatan pelajar, mahasiswa, dan masyarakat, sehingga menyebabkan jatuh korban yang lebih banyak, dan melibatkan aparat Kepolisian untuk mengantisipasinya. sehingga dalam Jumal ini penulis tertarik untuk meneliti mengenai Faktor yang menjadi penyebab terjadinya tindak pidana penyalahgunaan senjata tajam, Kendala yang ditemui dalam penegakan hukum bagi pelaku penyalahgunaan senjata tajam, Upaya dalam meminimalisir penggunaan senjata tajam. Metode penelitian yang digunakan dalam penulisan jumal ini adalah dengan menggunakan metode kualitatif yaitu mencari data dengan melakukan interview mengenai fenomena penyalahgunaan senjata tajam yang terjadi di sekitar Kota Sukabumi, Pendekatan Penelitian Yuridis Sosiologis adalah menekankan penelitian yang bertujuan memperoleh pengetahuan hukum secara empiris dengan jalan terjun langsung ke objeknya. Berdasarkan hasil penelitian penulis, kasus penyalahgunaan senjata tajam yang terjadi di Sukabumi terjadi karena faktor solidaritas atau kebersamaan antar warga yang dianiaya oleh warga lain yang menimbulkan kerusuhan dengan senjata tajam.
\end{abstract}

Kata Kunci : Kejahatan; Kriminogen; Pidana; Senjata.

\section{ABSTRACT}

Crimes that occur in society are a violation of positive law, namely criminal law. The use of sharp weapons in general is often used in brawls that are carried out both at the student level, students, and the community, causing more victims to fall, and involving the police to anticipate it. so that in this journal the authors are interested in researching the factors that cause criminal acts of abuse of sharp weapons, the obstacles encountered in law enforcement for perpetrators of the abuse of sharp weapons, efforts to minimize the use of sharp weapons. The research method used in writing this joumal is to use the method Qualitative research is to find data by conducting interviews about the phenomenon of sharp weapon abuse that occurs around Sukabumi City, the Sociological Juridical Research Approach is to emphasize research that aims to obtain legal knowledge empirically by going directly to the object. Based on the results of the author's research, cases of abuse of sharp weapons that occurred in Sukabumi occurred because of the solidarity factor or togethemess between residents who were persecuted by other residents who caused riots with sharp weapons.

Keywords $\quad$ : Crime; Criminogens; Criminal; Weapon. 


\section{A. PENDAHULUAN}

Negara Republik Indonesia merupakan suatu negara hukum di mana kekuasaan tunduk pada hukum (Sidharta, 2000). Sebagai negara hukum, maka hukum mempunyai kedudukan paling tinggi dalam pemerintahan, hukum adalah perlindungan kepentingan manusia (Mertokusumo, 2003). Hukum mengatur segala hubungan antar individu atau perorangan dan individu dengan kelompok atau masyarakat maupun individu dengan pemerintah (Sidharta, 2000).

Prinsip negara hukum menjamin kepastian, ketertiban, dan perlindungan hukum yang berintikan kebenaran dan keadilan (Supriadi, 2008). Kepastian, ketertiban dan perlindungan hukum menuntut antara lain bahwa lalu lintas hukum dalam kehidupan masyarakat memerlukan adanya alat bukti yang menentukan dengan jelas hak dan kewajiban seseorang sebagai subjek hukum dalam masyarakat, untuk mengatur segala hubungan antar manusia di atas (baik hubungan antar individu atau antara perorangan, maupun antara perorangan dengan kelompok-kelompok maupun antara individu atau kelompok dengan pemerintah), diperlukan hukum (Supriadi, 2008).

Tuntutan terhadap perlindungan hukum dalam kehidupan masyarakat salah satunya tercermin dalam lalu lintas hukum pembuktian, yaitu perlunya akta otentik. Negara Republik Indonesia merupakan suatu negara hukum di mana kekuasaan tunduk pada hukum (Reksodiputro, 1994). Sebagai negara hukum, maka hukum mempunyai kedudukan paling tinggi dalam pemerintahan, hukum adalah perlindungan kepentingan manusia (Efendi, 2005). Salah satu kejahatan yang meresahkan masyarakat adalah kejahatan dengan menggunakan senjata tajam. Kejahatan ini banyak macamnya, misalnya tindak pidana pembunuhan, penganiayaan berat, pencurian dengan pemberatan, pengancaman, penculikan, dan sebagainya. Kesemua jenis tindak pidana ini diatur dalam Kitab Undang-Undang Hukum Pidana di Indonesia (Lamintang, 1997).

Kejahatan yang terjadi di masyarakat merupakan sebuah pelanggaran terhadap hukum positif, yaitu hukum pidana. Kejahatan dan pelanggaran yang diatur dalam Kitab Undang-Undang Hukum Pidana dapat dilihat sebagai hukum pidana objektif, yaitu suatu tindak pidana yang digolongkan menurut ketentuanketentuan hukum itu sendiri dan hukum pidana subjektif, yaitu ketentuan- 
ketentuan di dalam hukum mengenai hak penguasa menerapkan hukum (Kartonegoro, 2004).

Secara umum dalam dunia masyarakat yang majemuk tidak terlepas dari sebuah problema kemasyarakatan, yang biasanya berujung pada sebuah aksi perkelahian yang melibatkan senjata tajam bahkan banyak di jumpai mahasiswamahasiswa ataupun para peajar yang sedang bertengkar akibat dari sebuah perbedaan pendapat yang berujung pada perkelahian individu, dari perkelahian individu inilah yang kadang membesar dan melibatkan banyak orang dalam jumlah yang besar, sehingga terjadi aksi tawuran yang terkadang menggunakan senjata tajam, sebagai tindakan-tindakan devensif dan opensif yang dilakukan oleh sekumpulan orang.

Eksistensinya, meskipun senjata tajam sangat bermanfaat dan diperlukan dalam hal mempersenjatai diri atau mempertahankan atau membela diri dari halhal yang mengancam jiwa, namun apabila disalahgunakan atau penggunaannya tidak sesuai dengan peraturan undang-undang yang berlaku, terlebih lagi dengan banyaknya penjual senjata tajam yang dilakukan secara illegal, maka akan menimbulkan akibat yang sangat merugikan perorangan maupun masyarakat, bahkan dapat menimbulkan bahaya yang lebih besar bagi kehidupan dan nilainilai budaya bangsa yang akhirnya dapat melemahkan ketahanan nasional.

Secara umum, arus kejahatan dengan menggunakan ancaman kekerasan maupun dengan senjata tajam yang terjadi memang sangat mengganggu keamanan dan ketertiban masyarakat, sehingga menimbulkan kekhawatiran di masyarakat. Kejahatan-kejahatan tersebut pun tidak memandang bulu, semua kalangan dapat mengalami dan merasakannya, mulai dari kalangan masyarakat biasa, hingga aparat sendiri. Penggunaan senjata tajam secara umum kerap digunakan dalam aksi tawuran yang dilakukan baik dalam tingkatan pelajar, mahasiswa, dan masyarakat, sehingga menyebabkan jatuh korban yang lebih banyak, dan melibatkan aparat Kepolisian untuk mengantisipasinya. Kejadian ini sangat meresahkan masyarakat dan aparat Kepolisian memerlukan penaganan serius, sehingga kepemilikan senjata tajam tanpa hak milik tidak dibenarkan sesuai dengan Undang-Undang Republik Indonesia Nomor 12/DRT/Tahun 1951 Tentang Senjata Api, Lembaran Negara Nomor 78 Tahun 1951. Undang-Undang 
Nomor 12/DRT/Tahun 1951 Tentang Senjata Api ini dibuat untuk mencegah agar tidak terjadi penyalahgunaan senjata api, bahan peledak, dan senjata tajam. Hal ini dapat dilihat dengan diberikanya ancaman hukuman sepuluh tahun penjara oleh pembuat undang-undang.

Faktor Kriminogen menurut Antonius Napitupulu adalah suatu faktor yang menyebabkan munculnya suatu tindak pidana baru (Abdussalam, 2007). Faktor Krominogen ini dapat dicontohkan dalam kasus pelaksanaan penangkapan yang dilakukan di lingkungan masyarakat yang padat penduduk atau perkampungan, di mana masyarakat memiliki jiwa kekerabatan yang kuat, sehingga kepedulian sosial masyarakat sangat kental (Abdussalam, 2007).

Indonesia sebagai salah satu negara yang berdasarkan Rule of Law sangat menjunjung tinggi Hak Asasi Manusia (HAM) yang diwujudkan dengan mengaturnya dalam berbagai peraturan, diantaranya dalam Undang-Undang Dasar Negara Republik Indonesia Tahun 1945 sebagai hukum dasar (Groundnorm). Pada bagian Pembukaan Undang-Undang Dasar Negara Republik Indonesia Tahun 1945 mengamanatkan bahwa negara dan pemerintah didirikan untuk melindungi segenap bangsa dan tanah tumpah darah Indonesia, mencerdaskan kehidupan bangsa, dan kesejahteraan umum (Nuraeny, 2012). Negara Pancasila mengakui manusia sebagai individu yang mempunyai hak dan kebebasan, tetapi sekaligus mengakui bahwa secara fitrah manusia itu juga adalah mahluk sosial yang tidak dapat menjadi manusiawi kalau tidak hidup bersama manusiamanusia lain. Dalam konsep keseimbangan yang seperti ini, maka Pancasila bukanlah penganut konsep individualisme yang memutlakan hak dan kebebasan individu, tetapi juga bukan penganut konsep kolektivisme yang mau menyamakan semua manusia begitu saja tanpa menghargai hak dan kebebasan individu (Mulyadi, 2014).

Upaya penegakan hukum yang dilakukan oleh pemerintah tidak dapat dilepaskan dari peran Kepolisian. Tugas pokok Kepolisian dalam perspektif Undang-Undang Republik Indonesia Nomor 2 Tahun 2002 Tentang Kepolisian Negara Republik Indonesia adalah memelihara keamanan dan ketertiban masyarakat, menegakan hukum, serta memberikan perlindungan, pengayoman dan pelayanan kepada masyarakat (Muladi, 2005). 
Jika diamati secara seksama mengenai kasus penganiayaan secara bersamasama dengan menggunakan senjata tajam, dapat diinterpretasikan bahwa pelaku penganiayaan sudah cukup untuk dijerat dengan Pasal 170 Kitab Undang-Undang Hukum Pidana, yang menyebutkan :

1. Barangsiapa dengan terang-terangan dan dengan tenaga bersama menggunakan kekerasan terhadap orang atau barang, diancam dengan pidana penjara paling lama lima tahun enam bulan;

2. Yang bersalah diancam :

a. Dengan pidana penjara paling lama tujuh tahun, jika ia dengan sengaja menghancurkan barang atau jika kekerasan yang digunakan mengakibatkan luka-luka;

b. Dengan pidana penjara paling lama sembilan tahun, jika kekerasan mengakibatkan luka berat;

c. Dengan pidana penjara paling lama dua belas tahun, jika kekerasan mengakibatkan maut".

Selanjutnya Pasal 169 Kitab Undang-Undang Hukum Pidana, yang menyebutkan:

1. Turut serta dalam perkumpulan yang bertujuan melakukan kejahatan. atau turut serta dalam perkumpulan lainnya yang dilarang oleh aturan-aturan umum, diancam dengan pidana penjara paling lama enam tahun;

2. Turut serta dalam perkumpulan yang bertujuan melakukan pelanggaran, diancam dengan pidana penjara paling lama sembilan bulan atau pidana denda paling banyak empat ribu lima ratus rupiah;

3. Terhadap pendiri atau pengurus, pidana dapat ditambah sepertiga".

Adapun Pasal 55 Kitab Undang-Undang Hukum Pidana menyebutkan :

1. Dipidana sebagai pelaku tindak pidana :

a. Mereka yang melakukan, yang menyuruh melakukan, dan yang turut serta melakukan perbuatan;

b. Mereka yang dengan memberi atau menjanjikan sesuatu dengan menyalahgunakan kekuasaan atau martabat, dengan kekerasan, ancaman atau penyesatan, atau dengan memberi kesempatan, sarana atau keterangan, sengaja menganjurkan orang lain supaya melakukan perbuatan.

2. Terhadap penganjur, hanya perbuatan yang sengaja dianjurkan sajalah yang diperhitungkan, beserta akibat-akibatnya”.

Selanjutnya Pasal 56 Kitab Undang-Undang Hukum Pidana, yang menyebutkan bahwa:

Dipidana sebagai pembantu kejahatan :

1. Mereka yang sengaja memberi bantuan pada waktu kejahatan dilakukan; 
2. Mereka yang sengaja memberi kesempatan, sarana atau keterangan untuk melakukan kejahatan".

Kemudian Pasal 2 ayat (1) Undang-Undang Republik Indonesia Nomor 12/DRT/ Tahun 1951 Tentang Senjata Api yang menyebutkan bahwa :

"Barangsiapa yang tanpa hak memasukkan ke Indonesia, membuat, menerima, mencoba memperolehnya, menyerahkan atau mencoba menyerahkan, menguasai, membawa, mempunyai persediaan padanya atau mempunyai dalam miliknya, menyimpan, mengangkut, menyembunyikan, mempergunakan atau mengeluarkan dari Indonesia sesuatu senjata pemukul. Senjata penikam atau senjata penusuk (Slag, Steek, of Stootwapen), dihukum dengan hukuman penjara setinggi-tingginya 10 (sepuluh) tahun”.

Jika mencermati isi dari Pasal 2 ayat (1) Undang-Undang Republik Indonesia Nomor 12/DRT/Tahun 1951 Tentang Senjata Api tersebut, salah satu unsur dari pasal tersebut adalah "tanpa hak" yang mengacu pada kepemilikan senjata tajam. Dalam berbagai peraturan perundang-undangan di Indonesia, baik dari yang paling tinggi hingga yang paling bawah, tidak akan menemukan sebuah regulasi yang mengatur tentang pemberian ijin atas kepemilikan senjata tajam. Berbeda dengan senjata api yang regulasi kepemilikannya diatur dengan jelas dalam Peraturan Kepala Kepolisian Republik Indonesia.

Pasal 2 ayat (2) Undang-Undang Republik Indonesia Nomor 12/DRT/ Tahun 1951 Tentang Senjata Api menyebutkan :

"Dalam pengertian senjata pemukul, senjata penikam atau senjata penusuk dalam pasal ini, tidak termasuk barang-barang yang nyata-nyata dimaksudkan untuk dipergunakan guna pertanian, atau untuk pekerjaanpekerjaan rumah tangga atau untuk kepentingan melakukan dengan syah pekerjaan atau yang nyata-nyata mempunyai tujuan sebagai barang pusaka atau barang kuno atau barang ajaib (merkwaardigheid)".

\section{B. METODE}

Penelitian yang akan digunakan dalam pelaksanaan penelitian ini dengan menggunakan metode penelitian lapangan (Field Research), yaitu mencari data dengan melakukan interview mengenai fenomena penggunaan senjata tajam yang terjadi di sekitar Kota Sukabumi. Keterangan fakta yang diperoleh langsung dari hasil wawancara dengan anggota Kepolisian Sektor Sukaraja Resor Sukabumi, mengenai penggunaan senjata tajam dan akibat-akibat hukumnya. Sebagaimana dalam Undang-Undang Nomor 23 tahun 2004 tentang Penghapusan Kekerasan 
dalam Rumah Tangga, kebijakan undang-undang lain yang berkaitan dengan permasalahan, dan literatur-literatur yang berkaitan dengan permasalahan dalam rangka menunjang kelengkapan informasi yang ada. Penelitian ini, dibutuhkan beberapa teknik pengumpulan data untuk mendapatkan informasi data primer dan data sekunder yang hasilnya nanti akan dianalisis,Teknik pengumpulan data yang digunakan dalam penelitian ini adalah Wawancara Yaitu satu percakapan dengan tujuan. Tujuan dari wawancara sendiri adalah untuk memperoleh konstruksi yang terjadi saat ini mengenai permasalahan penggunaan senjata tajam yang ada dan terjadi di Sukabumi. Pelaksanaan wawancara dalam rangka mendalami dan menjadi bahan tambahan data. Penelitian ini merupakan penelitian kualitatif yaitu jenis penelitian yang tidak didapatkan melalui prosedur hitungan atau statistik.

\section{HASIL ATAU PEMBAHASAN}

Hukum pidana yaitu bagian dari keseluruhan hukum yang berlaku di suatu negara, yang mengadakan dasar-dasar dan aturan-aturan untuk :

1. Menentukan perbuatan-perbuatan yang tidak boleh dilakukan, yang dilarang, dengan disertai ancaman atau sanksi berupa pidana tertentu bagi barang siapa yang melanggar larangan tersebut;

2. Menentukan dan dalam hal apa kepada mereka yang melanggar laranganlarangan itu dapat dikenakan atau dijatuhi pidana sebagaimana yang telah diancamkan;

3. Menentukan dengan cara bagaimana pengenaan pidana itu dapat dilakasanakan apabila orang yang disangkakan telah melanggar larangan tersebut (Moeljatno, 1980).

Hukum pidana di Indonesia terbagi dua yaitu hukum pidana umum dan pidana khusus. Secara definitif, hukum pidana umum dapat diartikan sebagai perundang-undangan pidana dan berlaku umum yang tercantum dalam Kitab Undang-Undang Pidana serta peraturan perundang-undangan yang mengubah dan menambah Kitab Undang-Undang Pidana. Contohnya dengan keluarnya UndangUndang Republik Indonesia Nomor 7 Tahun 1974 Tentang Penerbitan Perjudian diundangkan dan mulai berlaku pada tanggal 6 November 1974, yang mana dalam Pasal 1 undang-undang tersebut menyatakan bahwa semua tindak pidana perjudian sebagai kejahatan. Oleh karena itu, ketentuan-ketentuan mengenai perjudian yang dinyatakan dalam beberapa Pasal Kitab Undang-Undang Pidana 
perlu diadakan perubahan adapun perubahan dimaksud menyangkut ancaman hukuman bagi pelanggarnya (Prodjodikoro, 2003).

Hukum pidana khusus dapat dimaknai sebagai perundang-undangan di bidang tertentu yang memiliki sanksi pidana, atau tindak pidana yang diatur dalam perundang-undangan khusus di luar Kitab Undang-Undang Pidana. Menurut Andi Hamzah yang dimaksud hukum pidana khusus adalah peraturan hukum pidana yang tercantum di luar Kitab Undang-Undang Hukum Pidana dapat disebut undang-undang pidana tersendiri atau disebut juga hukum pidana di luar kodifikasi atau non kodifikasi (Hamzah, 1994).

Menurut Adami Chazawi yang dimaksud hukum pidana umum adalah hukum pidana yang ditujukan dan berlaku untuk semua warga negara (sebagai subjek hukum) dan tidak membeda-bedakan kualitas pribadi subjek hukum tertentu dan setiap warga negara harus tunduk dan patuh terhadap ketentuan tersebut. Sedangkan hukum pidana khusus adalah hukum pidana yang dibentuk oleh negara yang hanya dikhususkan berlaku bagi subjek hukum tertentu saja. Misalnya kejahatan jabatan bagi orang-orang warga negara yang berkualitas sebagai pegawai negeri atau hukum pidana yang termuat dalam Kitab UndangUndang Hukum Pidana Tentara (KUHPT) yang hanya berlaku bagi subjek hukum anggota Tentara Nasional Indonesia saja (Chazawi, 2002).

Hukum pidana menurut C.S.T. Kansil adalah hukum yang mengatur pelanggaran-pelanggaran dan kejahatan-kejahatan terhadap kepentingan umum, perbuatan yang diancam dengan hukuman yang merupakan suatu penderitaan atau siksaan (Kansil, 2014). Menurut W.L.G. Lemaire, hukum pidana terdiri dari norma-norma yang berisi keharusan-keharusan dan larangan-larangan yang (oleh pembentuk undang-undang) telah dikaitkan dengan suatu sanksi berupa hukuman, yakni suatu penderitaan yang bersifat khusus. Dengan demikian, dapat dikatakan bahwa hukum pidana merupakan suatu sistem norma-norma yang menentukan terhadap tindakan-tindakan yang mana (hal melakukan sesuatu atau tidak melakukan sesuatu di mana terdapat suatu keharusan untuk melakukan sesuatu) dan dalam keadaan-keadaan bagaimana hukum itu dapat dijatuhkan, serta pidana yang bagaimana yang dapat dijatuhkan bagi tindakan-tindakan tersebut(Lamintang, 1997). 
Menurut D. Simons, hukum pidana dapat dibagi menjadi hukum pidana dalam arti objektif atau strafrecht in objectieve zin dan hukum pidana dalam arti subjektif atau strafrecht in subjectieve zin. Hukum pidana dalam arti objektif adalah hukum pidana yang berlaku, atau yang juga disebut sebagai hukum positif atau ius poenale (Lamintang, 1997). Menurut W.F.C. van Hattum, hukum pidana adalah suatu keseluruhan dari asas-asas dan peraturan-peraturan yang diikuti oleh negara atau suatu masyarakat hukum umum lainnya, di mana mereka itu sebagai pemelihara dari ketertiban hukum umum telah melarang dilakukannya tindakantindakan yang bersifat melanggar hukum dan telah mengaitkan pelanggaran terhadap peraturan-peraturannya dengan suatu penderitaan yang bersifat khusus berupa hukuman (Lamintang, 1997).

van Kant menyebutkan bahwa hukum pidana tidak mengadakan normanorma baru dan tidak menimbulkan kewajiban-kewajiban yang dulunya belum ada. Hanya norma-norma yang sudah ada saja yang dipertegas, yaitu dengan mengadakan ancaman pidana dan pemidanaan. Hukum pidana memberikan sanksi yang bengis dan sangat memperkuat berlakunya norma-norma hukum yang telah ada. Tetapi tidak mengadakan norma baru. Hukum pidana sesungguhnya adalah hukum sanksi (het strafrecht is wezenlijk sanctie-recht)(Lamintang, 1997).

W.P.J. Pompe menyimpulkan behwa hukum pidana adalah semua aturanaturan hukum yang menentukan terhadap perbuatan-perbuatan apa seharusnya dijatuhi pidana dan apakah macamnya pidana itu (Lamintang, 1997). Menurut Hazewinkel \& Suringa, hukum pidana adalah sejumlah peraturan hukum yang mengandung larangan dan perintah atau keharusan yang terhadap pelanggarannya diancam dengan pidana (sanksi hukum) bagi barang siapa yang membuatnya (Hamzah, 1994).

Adami Chazawi menegaskan bahwa hukum pidana itu adalah bagian dari hukum publik yang memuat atau berisi ketentuan-ketentuan tentang :

1. Aturan umum hukum pidana dan (yang dikaitkan atau berhubungan dengan) larangan melakukan perbuatan-perbuatan (aktif atau positif maupun pasif atau negatif) tertentu yang disertai dengan ancaman sanksi berupa pidana (straf) bagi yang melanggar larangan itu; 
2. Syarat-syarat tertentu (kapankah) yang harus dipenuhi atau harus ada bagi pelanggar untuk dapat dijatuhkannya sanksi pidana yang diancamkan pada larangan perbuatan yang dilanggarnya;

3. Tindakan dan upaya-upaya yang boleh atau harus dilakukan negara melalui alat-alat perlengkapannya (misalnya Polisi, Jaksa, Hakim), terhadap yang disangka dan didakwa sebagai pelanggar hukum pidana dalam rangka usaha negara menentukan, menjatuhkan dan melaksanakan sanksi pidana terhadap dirinya, serta tindakan dan upaya-upaya yang boleh dan harus dilakukan oleh tersangka atau terdakwa pelanggar hukum tersebut dalam usaha melindungi dan mempertahankan hak-haknya dari tindakan negara dalam upaya negara menegakkan hukum pidana tersebut (Chazawi, 2002).

Menurut E.Y. Kanter dan S.R. Sianturi, hukum pidana adat pun yang tidak dibuat oleh negara atau political authority masih mendapat tempat dalam pengertian hukum pidana. Hukum adat tumbuh dan berakar dalam kesadaran dan pergaulan hidup masyarakat. Kenyataan masih berlakunya hukum adat di Indonesia sampai saat ini tidak dapat dipungkiri, dengan demikian maka perumusan hukum pidana adalah bagian dari hukum positif yang berlaku di suatu negara dengan memperhatikan waktu, tempat dan bagian penduduk, yang memuat dasar-dasar dan ketentuan-ketentuan mengenai tindakan larangan atau tindakan keharusan dan kepada pelanggarnya diancam dengan pidana. Menentukan pula jika dan dalam hal apa pelaku pelanggaran tersebut dipertanggungjawabkan, serta ketentuan-ketentuan mengenai hak dan cara Penyidikan, Penuntutan, penjatuhan pidana dan pelaksanaan pidana demi tegaknya hukum yang bertitik berat kepada keadilan. Perumusan ini mencakup juga hukum (pidana) adat, serta bertujuan mengadakan keseimbangan diantara berbagai kepentingan atau keadilan (Sianturi, 1981).

Berdasarkan beberapa pendapat yang telah dikutip di atas, Penulis menginterpretasikan tentang hukum pidana yaitu hukum pidana setidaknya merupakan hukum yang mengatur tentang :

1. Larangan untuk melakukan suatu perbuatan;

2. Syarat-syarat agar seseorang dapat dikenakan sanksi pidana; 
3. Sanksi pidana apa yang dapat dijatuhkan kepada seseorang yang melakukan suatu perbuatan yang dilarang (delik);

4. Cara mempertahankan atau memberlakukan hukum pidana.

Faktor kriminogen adalah suatu faktor yang menyebabkan munculnya suatu tindak pidana baru. Faktor krominogen ini dapat penulis contohkan dalam kasus pelaksanaan penangkapan yang dilakukan dilingkungan masyarakat yang padat atau perkampungan, di mana masyarakat memiliki jiwa kekerabatan yang kuat, sehingga kepedulian sosial masyarakat sangat kental. Penangkapan pada daerah seperti ini apabila tidak dilakukan dengan cermat, koordinasi serta tidak sesuai prosedur akan dapat membahayakan tidak hanya bagi masyarakat sekitar tetapi juga dapat membahayakan anggota Polisi itu sendiri di lapangan yang melakukan penangkapan tersebut, seperti terjadinya pengeroyokan dan penganiayaan oleh warga masyarakat terhadap anggota Polisi. Pengeroyokan dan penganiayaan inilah yang disebut sebagai faktor kriminogen (muculnya tindak pidana baru), yang muncul pada saat penangkapan yang dilakukan oleh Polisi.

Contoh lain dapat Penulis gambarkan kasus model perampokan yang pelakunya tidak mengindahkan petugas pengawal, Satpam, atau sejenisnya. Pelaku "menyikat" siapa pun yang menghalangi aksinya. Bersamaan dengan itu, pelaku menodongkan senjata (dapat senjata api ataupun senjata tajam), dan bila ada tanda-tanda korban melawan, pelaku mencederainya. Setelah itu, bahkan kadang dengan tenang pelaku melenggang membawa jarahannya.

Seringkali dalam pola hubungan antar individu dan kolompok menimbulkan sebuah kesalahpahaman dan konflik, sehingga seringkali terjadi konflik yang berkelanjutan, dan untuk menyelesaikan biasanya individu atau kelompok menggunakan senjata tajam sebagai bentuk dari defensive dan opensif yang dilakukan (Zahroni, 2014).

Berbagai perkelahian yang terjadi antar pelajar, mahasiswa atau kelompok masyarakat biasanya diwarnai dengan berbagai senjata tajam sebagai alat perkelahian. Hal ini didasarkan sebagai bentuk defensive dan opensif yang ditunjukkan oleh para pihak atau kelompok masyarakat. Tak jarang dari aksi perkelahian ini menimbulkan korban antara kedua pihak, bahkan sampai ada yang meninggal dunia. 
Kejahatan atau yang lebih dikenal dengan istilah "tindak pidana" merupakan salah satu masalah sosial yang sangat meresahkan manusia dalam melakukan aktivitas dan kegiatan hidupnya sehari-hari. Kejahatan telah menempati tempat teratas sebagai sasaran pembahasan dalam berbagai kalangan pakar-pakar ilmu pengetahuan dan ilmu hukum. Hal ini terbukti dengan banyaknya berita tentang berbagai tindak pidana pembunuhan, perampokan, pencurian maupun tindak pidana yang berhubungan dengan kesusilaan (Saleh, 2001).

Berbagai upaya telah dilakukan guna menghilangkan tindak kejahatan dari permukaan bumi, namun kejahatan tersebut tidak pernah sirna dari peradaban umat manusia. Kejahatan memang tidak dapat dihapuskan dari muka bumi, karena kejahatan tumbuh dan berkembang sejalan dengan kebudayaan manusia dan dilakukan oleh manusia sebagai salah satu sub sistem pendukung peradaban meskipun kejahatan tidak dikehendaki kelahirannya oleh masyarakat. Namun kejahatan akan selalu tumbuh dalam masyarakat, sebab dilakukan oleh salah satu anggota masyarakat tersebut(Saleh, 2001).

Meskipun pada hakikatnya kejahatan tidak mungkin dihilangkan dari muka bumi, namun sebagai manusia yang dibekali dengan akal pikiran, tidak dapat berpangku tangan melihat berbagai kemungkaran yang terjadi. Kejahatan merupakan perbuatan anti sosial yang meresahkan masyarakat dalam melakukan interaksi dengan sesamanya di mana perbuatan tersebut mendapat tantangan dari pemerintah atau negara. Secara yuridis, kejahatan dapat dikatakan sebagai suatu perbuatan melawan hukum di mana sebagai akibat dari perbuatan itu, pelaku dapat dikenakan sanksi sebagaimana termaktub dalam peraturan undang-undang yang dilanggar.

Senjata adalah suatu alat yang digunakan untuk melukai, membunuh, atau menghancurkan suatu benda. Senjata dapat digunakan untuk menyerang maupun untuk mempertahankan diri, dan juga untuk mengancam dan melindungi. Apapun yang dapat digunakan untuk merusak (bahkan psikologi dan tubuh manusia) dapat dikatakan senjata. Senjata dapat sederhana seperti pentungan atau kompleks seperti peluru kendali balistik. Senjata tajam adalah alat yang ditajamkan untuk digunakan langsung untuk melukai tubuh lawan(Senjata, 2021). 
Di dalam Undang-Undang Republik Indonesia Nomor 2 Tahun 2002

Tentang Kepolisian Negara Republik Indonesia pada penjelasan Pasal 15 ayat (2) huruf e juga disebutkan pengertian senjata tajam yaitu :

"Yang dimaksud dengan "senjata tajam" dalam undang-undang ini adalah senjata penikam, senjata penusuk, dan senjata pemukul, tidak termasuk barang-barang yang nyata-nyata dipergunakan untuk pertanian, atau untuk pekerjaan rumah tangga, atau untuk kepentingan melakukan pekerjaan yang sah, atau nyata untuk tujuan barang pusaka, atau barang kuno, atau barang ajaib sebagaimana diatur dalam Undang-Undang Nomor 12/Drt/1951”.

Jika mencermati isi dari Pasal 2 ayat (1) Undang-Undang Republik Indonesia Nomor 12/Drt/Tahun 1951 yang menyatakan sebagai berikut :

"Barangsiapa yang tanpa hak memasukkan ke Indonesia, membuat, menerima, mencoba memperolehnya, menyerahkan atau mencoba menyerahkan, menguasai, membawa, mempunyai persediaan padanya atau mempunyai dalam miliknya, menyimpan, mengangkut, menyembunyikan, mempergunakan atau mengeluarkan dari Indonesia sesuatu senjata pemukul, senjata penikam, atau senjata penusuk (slag-, steek-, of stootwapen), dihukum dengan hukuman penjara setinggi-tingginya sepuluh tahun".

Salah satu unsur dari pasal ini adalah "tanpa hak" yang mengacu pada kepemilikan senjata tajam. Dalam berbagai peraturan perundang-undangan di Indonesia, tidak ada regulasi yang mengatur tentang pemberian ijin atas kepemilikan senjata tajam. Berbeda dengan senjata api, yang regulasi kepemilikannya diatur dengan jelas dalam Peraturan Kepala Kepolisian Republik Indonesia.

Tapi perlu juga dicermati, dalam Pasal 2 ayat (2) Undang-Undang Republik Indonesia Nomor 12/Drt/Tahun 1951 Tentang Senjata Api disebutkan :

"Dalam pengertian senjata pemukul, senjata penikam atau senjata penusuk dalam pasal ini, tidak termasuk barang-barang yang nyata-nyata dimaksudkan untuk dipergunakan guna pertanian, atau untuk pekerjaanpekerjaan rumah tangga atau untuk kepentingan melakukan dengan syah pekerjaan atau yang nyata-nyata mempunyai tujuan sebagai barang pusaka atau barang kuno atau barang ajaib (merkwaardigheid)".

Berdasarkan ketentuan pasal di atas dapat dilihat pengecualian yang diberikan undang-undang ini. Senjata tajam yang dipergunakan guna pertanian atau untuk pekerjaan rumah tangga atau melakukan pekerjaan lainnya. Jika dicontohkan secara sederhana, seorang petani yang membawa celurit untuk membersihkan rumput di sawah, tidak dapat dikenakan ancaman pidana 
membawa senjata tajam tanpa hak, karena dalam hal ini senjata tajam tersebut digunakan untuk pertanian dan pekerjaan si petani tersebut.

Bahwa setiap orang yang membawa senjata tajam tanpa hak dapat dikenakan ancaman pidana. Oleh sebab itu, jika tidak untuk keperluan pekerjaan, lebih baik tidak membawa senjata tajam ketika bepergian. Adapun alasan-alasan untuk jaga diri, tidak dapat diterima sebagai alasan pembenar apabila suatu ketika tertangkap membawa senjata tajam.

Arus kejahatan dengan menggunakan ancaman kekerasan maupun dengan senjata tajam yang terjadi di Kota Sukabumi memang sangat mengganggu keamanan dan ketertiban masyarakat, sehingga menimbulkan kekhawatiran di masyarakat. Kejahatan-kejahatan tersebut pun tidak memandang bulu, semua kalangan dapat mengalami dan merasakannya, mulai dari kalangan masyarakat biasa, pendidikan, seperti guru, dosen, dan lain-lain, pengusaha, bahkan kalangan aparat penegak hukum sendiri seperti Kepolisian maupun Tentara Nasional Indonesia sendiri.

Dampak negatif jika masyarakat khususnya anak yang masih di bawah umur membawa senjata tajam adalah para pihak akan berurusan dengan pihak aparat Kepolisian, belum lagi yang awalnya membawa senjata tajam hanya untuk dipakai sebagai pelindung diri tapi pada akhirnya digunakan untuk kepentingan lain seperti untuk membunuh orang dan sebagai gaya-gayaan. Sehubungan dengan banyaknya kasus atau delik yang terjadi akibat penyalahgunaan senjata tajam, maka tentunya perlu ada perhatian khusus supaya dapat meminimalisir kejadian delik ini karena mengingat wilayah hukum di daerah Sukabumi sangat rawan tentang delik membawa senjata tajam.

Kenyataannya, pelanggaran terhadap Pasal 2 Undang-Undang Republik Indonesia Nomor 12/Drt/Tahun 1951 Tentang Senjata Api seperti tertangkap karena membawa senjata tajam tidak digolongkan sebagai kejahatan, tetapi digolongkan sebagai pelanggaran. Baru digolongkan sebagai kejahatan apabila senjata tajam tersebut digunakan untuk membunuh atau menganiaya seseorang, belum lagi pengancaman atau penganiayaan dengan senjata tajam merupakam hal yang paling biasa dilakukan oleh masyarakat. Oleh karena itu, pengawasan secara berkesinambungan terhadap masyarakat yang membawa senjata tajam perlu 
ditingkatkan lagi. Bukan hanya aparat saja akan tetapi sebagai masyarakat perlu ada kesadaran terhadap hal tersebut.

Menurut Bawengan, dalam kehidupan bermasyarakat tidak terlepas dari berbagai problematika antar manusia yang dipicu oleh berbagai faktor. Hal ini sudah menjadi bagian dari kehidupan sosial masyarakat, sikap dan pola pikir dan interaksi yang terjadi didalam suatu lingkungan membawa berbagai perubahan kehidupan sosial kemasyarakatan dalam semua sendi kehidupan. Adanya berbagai pandangan yang berbeda-beda membuat hubungan antar individu yang satu dengan yang lainnya, bahkan kelompok harus saling berhubungan, sebagaimana sifat manusia sebagai zoon politicon atau mahluk yang bermasyarakat yang tidak dapat hidup tanpa bantuan orang lain Bawengan, 2007).

Perilaku yang menyimpang dalam masyarakat yang dimaksudkan adalah terjadinya perkelahian antar kelompok yang telah menimbulkan kerugian yang tidak sedikit, baik korban jiwa maupun harta benda. Disamping itu pula, keadaan masyarakat yang majemuk dengan pola dan tingkah laku yang berbeda-beda dapat pula mempengaruhi terjadinya kelakuan yang menyimpang dalam masyarakat heterogen berbaur menjadi satu badan kegiatan (Bawengan, 2007).

Era globalisasi saat ini, masyarakat lambat laun berkembang di mana perkembangan itu selalu diikuti proses penyesuaian diri yang terkadang proses tersebut terjadi secara tidak seimbang. Pelanggaran terhadap norma-norma tersebut dengan kata lain semakin sering terjadi dan kejahatan semakin bertambah baik jenis maupun bentuk polanya semakin kompleks. Di samping itu, sebagai dampak era globalisasi, kejahatan korporasi yang menonjol adalah price fixing (memainkan harga barang secara tidak sah), false advertising (penipuan iklan), seperti di bidang farmasi (obat-obatan), dan kejahatan lingkungan hidup (environmental crime), serta kejahatan perbankan (cyber crime, money laundering, ilegal logging) (Priyatno, 2012).

Akibat dari sebuah kemajuan jelas akan membawa dampak yang bukan hanya dampak positif yang akan dirasakan, tetapi juga melahirkan sebuah dampak negatif yang harus dihadapi sebagai konsekuensi kehidupan bermasyarakat. Salah satu dampak yang sering dirasakan dari sebuah kemajuan adalah dampak negatif, ini dibuktikan dengan semakin meningkatnya kejahatan baik dilihat dari sudut 
pandang kualitas maupun kuantitasnya. Salah satu faktor penyebabnya adalah kurangnya lapangan pekerjaan yang berakibat pengangguran merajalela di manamana. Faktor lain yang dapat memicu kejahatan akibat sebuah kemajuan yang begitu pesat tanpa diimbangi dengan kesiapan mental masyarakat adalah derasnya informasi-informasi baik melalui media cetak maupun media elektronika tanpa adanya sebuah filtrasi, oleh sebab itu kejahatan dari hari ke hari berkembang sejalan dengan perkembangan dan perubahan masyarakat (Simanjuntak, 2004).

Permasalahan yang sering terjadi di dalam kehidupan masyarakat sudah merupakan hukum alam sebagai bentuk dari mahluk sosial. Perubahan telah melanda pemahaman, penghayatan dan pengalaman serta keyakinan dan normanorma kepatuhan yang ada dalam masyarakat itu sendiri. Perubahan juga telah melanda tata pemahaman tata nilai dan adat istiadat, pola tingkah laku yang lama hidup dan berkembang dalam masyarakat (Gunarso, 2005).

Berdasarkan Berita Acara Pendapat (Resume) Kasus Penganiayaan Ormas Resor Sukabumi Kota, hlm. 1.Seperti halnya kasus yang terjadi mengenai penggunaan senjata tajam di muka umum oleh salah satu anggota masyarakat, yang dalam hal ini dilakukan oleh Sdr. Ali Reza melakukan tindak pidana secara bersama-sama melakukan kekerasan terhadap orang atau barang dan di muka umum dengan lisan atau tulisan menghasut supaya melakukan sesuatu perbuatan yang dapat dihukum, melawan pada kekuasaan umum dengan kekerasan atau supaya jangan mau menurut peraturan perundang-undangan atau perintah yang sah dan turut serta perkumpulan lainya yang dilarang aturan-aturaan umum dan setidak-tidaknya turut serta membantu atau setidak-tidaknya turut serta melakukan kejahatan dan/atau membawa senjata tajam tanpa hak atau atau ijin dan bukan peruntukkannya, yang terjadi pada hari Sabtu tanggal 01 November 2014 yang silam, sekitar pukul 20.30 Waktu Indonesia Barat (WIB) di Jalan Lingkar Selatan Kelurahan Jayaraksa Kecamatan Baros Kota Sukabumi tepatnya depan Showroom Andas terhadap korban Sdr. Angga Prayoga dan kawan-kawan.

Faktor penyebab terjadinya tindak pidana penyalahgunaan senjata tajam di kalangan masyarakat di muka umum adalah :

1. Faktor Internal 
Faktor internal terjadi di dalam diri individu itu sendiri yang berlangsung melalui proses internalisasi diri yang keliru dalam menyelesaikan permasalahan di sekitarnya dan semua pengaruh yang datang dari luar. Para pihak yang biasanya tidak mampu melakukan adaptasi dengan lingkungan yang kompleks. Maksudnya, para pihak atau kelompok tersebut tidak dapat menyesuaikan diri dengan keanekaragaman pandangan, ekonomi, sosial budaya dan berbagai keberagaman lainnya yang semakin lama semakin kompleks.

\section{Faktor Eksternal}

Selain faktor internal terjadinya tindak pidana penyalahgunaan senjata tajam, juga disebabkan faktor eksternal dan biasanya ini yang paling besar pengaruhnya terhadap para pihak dalam melakukan tindak pidana penyalahgunaan senjata tajam, antara lain sebagai berikut :

a. Faktor Lingkungan

Faktor lingkungan merupakan salah satu penyebab terjadinya tindak pidana penyalahgunaan senjata tajam bagi para pihak yang bertikai. Hal ini dapat terjadi sebab merupakan sifat bawaan dari lingkungan masing-masing yang sudah sering terlibat aksi perkelahian di daerahnya. Dari aksi perkelahian yang terjadi di lingkungannya sudah menggunakan senjata tajam. Dari faktor lingkungan inilah sehingga ketika terjadi aksi perkelahian menggunakan senjata tajam sebagai bentuk dari ego mempertahankan diri dan sebagai bentuk perlawanan yang dilakukannya.

b. Faktor Solidaritas atau Kebersamaan

Selain faktor lingkungan, penyebab terjadinya tindak pidana penyalahgunaan senjata tajam bagi kalangan pelajar atau mahasiswa adalah adanya rasa solidaritas atau kebersamaan bagi kelompok yang terlibat aksi perkelahian. Ini sebagai bentuk dari sebuah rasa saling menjaga dan saling melindungi serta saling membantu antar kelompoknya. Hal inilah faktor yang paling dominan di tingkat masyarakat.

\section{Faktor Teknologi}

Kemajuan teknologi mengantar perubahan yang sangat besar dalam kehidupan masyarakat yang menyentuh sendi-sendi kehidupan masyarakat baik dari perkotaan sampai pada daerah. Hal ini ditandai dengan banyaknya daerah- 
daerah yang sudah memperkenalkan hasil karya dari segi teknologi, baik dari alat rumahan sampai pada teknologi perang. Selain dari kemampuan menciptakan teknologi juga didukung karena adanya akses yang luas untuk mendapatkan barang-barang yang diinginkan, sehingga dengan mudahnya mengakses barangbarang yang diinginkan, tidak jarang ada pula oknum-oknum yang memanfaatkan kemudahan dari teknologi ini. Dari kemajuan teknologi ini banyak dari kalangan masyarakat ini mampu menciptakan sebuah senjata tajam.

\section{Faktor Sosial Budaya}

Kehidupan dengan adat istiadat yang berbeda-beda sebenarnya suatu alat untuk mempersatukan ikatan persaudaraan yang lebih tinggi. Namun, tidak jarang justru ini menjadi pemicu timbulnya perkelahian. Bentrokan antar satu kebudayaan yang lain akan melemahkan norma yang ada, sehingga kontrol sosial yang ada pada masyarakat akan melemah. Dengan melemahnya kontrol sosial tersebut, membuat individu yang membentuk suatu komunitas masyarakat akan bertindak sendiri tanpa mempedulikan lagi norma yang telah disepakati.

\section{Faktor Dendam}

Faktor dendam banyak mempengaruhi sebab terjadinya perkelahian di Sukabumi, dengan latar belakang dipermalukan atau tidak terima karena sudah dipukul oleh salah satu kelompok lain. Ini biasanya terjadi pada salah satu anggota kelompok yang tidak diterima karena dipukul, sehingga memberitahukannya kepada teman-teman kelompoknya, sehingga para pihak pun membalas apa yang dilakukan kepada anggota kelompoknya, dan perkelahian antar kelompok ini tidak terhindarkan lagi.

Secara konseptual, saat ini kejahatan-kejahatan yang sering terjadi di tengah-tengah masyarakat sangatlah beraneka ragam bentuknya, misalnya pencurian, penipuan, penganiayaan, penculikan, serta kasus kejahatan biasa lainnya sampai kejahatan yang menimbulkan rasa takut dan cemas terhadap masyarakat, seperti kasus dengan menggunakan senjata api, senjata tajam, pembunuhan dengan berbagai motif, kejahatan narkotika dan psikotropika, perdagangan wanita dan anak di bawah umur, serta kasus-kasus lainnya. Dengan begitu banyaknya terjadi kejahatan-kejahatan tersebut tidak diragukan lagi bahwa 
akan menimbulkan dampak yang sangat mengkhawatirkan terhadap masyarakat (Weda, 2004).

Meningkatnya jumlah kasus-kasus kriminalitas di kota-kota besar merupakan suatu tempat di mana bertumpuknya segala macam persoalanpersoalan yang dihadapi oleh komunitas masyarakat di kota-kota besar, terutama bagi aparat Kepolisian, di mana aparat Kepolisian tersebut mempunyai tugas yang sangat berat dalam menghadapi berbagai macam jenis tindak pidana kejahatan yang ada di kota-kota besar. Memang masih ada sisa-sisa kenyamanan dan keamanan di berbagai sudut kota, di rumah kediaman, kantor atau kampus, pusatpusat perbelanjaan, dan tempat-tempat hiburan. Tetapi kondisinya tetap saja menakutkan dan menyeramkan, karena adanya tindak kejahatan seperti pencopetan, pemerasan, penodongan, dan pencurian yang sewaktu-waktu dapat saja terjadi atas diri siapapun dan di manapun berada (Weda, 2004).

Tingginya tingkat kriminalitas yang terjadi di kota-kota besar biasanya disebabkan oleh faktor perekonomian seseorang. Hal ini dapat dilihat dari banyaknya pemberitaan mengenai kejahatan-kejahatan yang terjadi di kota-kota besar melalui media informasi yang ada. Kurangnya tingkat perekonomian yang berupa lapangan pekerjaan untuk golongan kelas menengah ke bawah dapat menimbulkan banyaknya jumlah pengangguran, serta meningkatnya harga-harga kebutuhan hidup yang juga dapat mengurangi pendapatan masyarakat, sehingga dari kondisi yang seperti ini dapat menimbulkan suatu tekanan-tekanan kebutuhan yang sangat besar, sehingga bagi para pihak yang imannya lemah akan lebih mudah untuk melakukan tindakan-tindakan kriminalitas (Weda, 2004).

Kendala yang ditemui dalam penegakan hukum bagi pelaku penyalahgunaan senjata tajam adalah bahwa senjata tajam dapat ditemukan di mana saja, mengingat belum ada pengaturan secara spesifik mengenai senjata tajam. Berbeda dengan senjata api, yang pengaturan mengenai senjata api jelas dan gamblang. Oleh karena itu, aparat penegak hukum menemui kendala yang cukup krusial dalam kerangka menekan atau meminimalisir penggunaan senjata tajam secara illegal.

Upaya dalam meminimalisir penggunaan senjata tajam, maka dari itu masalah kepemilikan senjata tajam illegal sudah diatur dalam beberapa peraturan 
perundang-undangan. Terdapat ketentuan tersendiri mengenai kepemilikan senjata tajam oleh masyarakat. Kepemilikan senjata tajam secara umum diatur dalam Undang-Undang Darurat Nomor 12 Tahun 1951 Tentang Senjata Api yang bersifat pidana. Pasal 2 ayat (2) Undang-Undang Republik Indonesia Nomor 12/Drt/Tahun 1951 Tentang Senjata Api menyebutkan bahwa :

(1) Barangsiapa yang tanpa hak memasukkan ke Indonesia, membuat, menerima, mencoba memperolehnya, menyerahkan atau mencoba menyerahkan, menguasai, membawa, mempunyai persediaan padanya atau mempunyai dalam miliknya, menyimpan, mengangkut, menyembunyikan, mempergunakan atau mengeluarkan dari Indonesia sesuatu senjata pemukul, senjata penikam, atau senjata penusuk (slag-, steek-, of stootwapen), dihukum dengan hukuman penjara setinggi-tingginya sepuluh tahun;

(2) Dalam pengertian senjata pemukul, senjata penikam atau senjata penusuk dalam Pasal ini, tidak termasuk barang-barang yang nyata-nyata dimaksudkan untuk dipergunakan guna pertanian, atau untuk pekerjaanpekerjaan rumah tangga atau untuk kepentingan melakukan dengan syah pekerjaan atau yang nyata-nyata mempunyai tujuan sebagai barang pusaka atau barang kuno atau barang ajaib (merkwaardigheid)".

Di dalam Pasal 2 ayat (2) Undang-Undang Republik Indonesia Nomor 12/Drt/Tahun 1951 Tentang Senjata Api diatur pengecualian penggunaan senjatasenjata yang disebutkan dalam ayat (1) yaitu :

"Tidak termasuk barang-barang yang nyata-nyata dimaksudkan untuk dipergunakan guna pertanian, atau untuk pekerjaan-pekerjaan rumah tangga atau untuk kepentingan melakukan dengan syah pekerjaan atau yang nyatanyata mempunyai tujuan sebagai barang pusaka atau barang kuno atau barang ajaib (merkwaardigheid)".

Berdasarkan ketentuan pasal di atas, terdapat cakupan yang luas mengenai kepemilikan senjata tajam yang diancam pidana dari membuat hingga mengeluarkan dari Indonesia suatu senjata tajam. Apabila kepemilikan senjata tajam di atas dilakukan tanpa hak, maka dapat dijatuhkan sanksi pidana berupa hukuman penjara hingga 10 (sepuluh) tahun.

Tanpa hak sebagai suatu kualifikasi pasal ancaman pidana di atas, dapat diartikan juga sebagai perbuatan melawan hukum dalam pidana. Tanpa hak di sini berarti bahwa pemilik senjata tajam itu tidak mempunyai kewenangan untuk memilikinya, atau tidak memiliki ijin kepemilikan. Jadi jelas, pertanggungjawaban hukum pidana bagi pelaku penyalahgunaan senjata tajam bagi masyarakat sudah diatur dalam sebuah undang-undang. Bagi para pihak 
ataupun masyarakat yang menggunakan senjata tajam yang bukan peruntukkannya dapat dijerat dengan Undang-Undang Republik Indonesia Nomor 12/Drt/Tahun 1951 Tentang Senjata Api Pasal 2 ayat (1).

Salah satu upaya yang dilakukan guna meminimalisir terjadinya penyalahgunaan senjata tajam di kalangan masyarakat adalah dengan mengadakan sosialisasi ke masyarakat, baik lewat door to door, maupun ke setiap sekolahsekolah yang ada di Kota Sukabumi, selain menggunakan sarana penal, yakni dengan menerapkan sanksi pidana maksimal bagi pelaku yang melakukan tindak pidana menggunakan senjata tajam.

\section{B. PENUTUP}

Faktor yang menjadi penyebab terjadinya tindak pidana penyalahgunaan senjata tajam di kalangan masyarakat di muka umum adalah solidaritas atau kebersamaan. Hal ini sebagai bentuk dari sebuah rasa saling menjaga dan saling melindungi serta saling membantu antar kelompoknya. Hal inilah faktor yang paling dominan di tingkat masyarakat. Selain itu, faktor dendam banyak mempengaruhi sebab terjadinya perkelahian di Sukabumi, dengan latar belakang dipermalukan atau tidak terima karena sudah dipukul oleh salah satu kelompok lain. Ini biasanya terjadi pada salah satu anggota kelompok yang tidak diterima karena dipukul, sehingga memberitahukannya kepada teman-teman kelompoknya, sehingga para pihak pun membalas apa yang dilakukan kepada anggota kelompoknya, dan perkelahian antar kelompok ini tidak terhindarkan lagi. Kendala yang ditemui dalam penegakan hukum bagi pelaku penyalahgunaan senjata tajam adalah bahwa senjata tajam dapat ditemukan di mana saja, mengingat belum ada pengaturan secara spesifik mengenai senjata tajam. Berbeda dengan senjata api, yang pengaturan mengenai senjata api jelas dan gamblang. Oleh karena itu, aparat penegak hukum menemui kendala yang cukup krusial dalam kerangka menekan atau meminimalisir penggunaan senjata tajam secara illegal. Upaya dalam meminimalisir penggunaan senjata tajam yaitu adanya sanksi hukum pidana bagi pelaku penyalahgunaan senjata tajam bagi masyarakat sudah diatur dalam sebuah undang-undang, bagi para pihak ataupun masyarakat yang menggunakan senjata tajam yang bukan peruntukkannya. 


\section{DAFTAR PUSTAKA}

Abdussalam, H. . (2007). Kriminologi. Restu Agung.

Bawengan, G. W. (2007). Masalah Kejahatan Dengan Sebab Dan Akibat. Pradnya Paramita.

Chazawi, A. (2002). Pelajaran Hukum Pidana Bagian 1. PT, Raja Grafindo Persada.

Efendi, M. (2005). Kejaksaan Republik Indonesia Posisi Dan Fungsinya Dari Perspektif Hukum. PT. Gramedia Pustaka Utama.

Gunarso, S. (2005). Psikologi Remaja. Gunung Mulia.

Hamzah, A. (1994). Asas-asas Hukum Pidana. Rineka Cipta.

Kansil. (2014). Pengantar Ilmu Hukum dan Tata Hukum Indonesia. Balai Pustaka.

Kartonegoro. (2004). Diktat Kuliah Hukum Pidana. Balai Lektur Mahasiswa.

Lamintang, P. A. F. (1997). Dasar-dasar Hukum Pidana Indonesia. PT. Citra Aditya Bakti.

Mertokusumo, S. (2003). Mengenal Hukum Suatu Pengantar. Liberty.

Moeljatno. (1980). Pokok-pokok Hukum Pidana. Fasco.

Muladi. (2005). Undang-Undang Nomor 2 Tahun 2002 Tentang Kepolisian Negara Republik Indonesia. PT. Raja Grafindo Persada.

Mulyadi, D. (2014). Internalisasi Nilai-nilai Ideologi Pancasila. Refika Aditama.

Nuraeny, H. (2012). Wajah Hukum Pidana, Asas Dan Perkembangan. Gramata Publishing.

Priyatno, M. \& D. (2012). Pertanggungjawaban Pidana Korporasi. Kencana Prenadamedia Group.

Prodjodikoro, W. (2003). Tindak-tindak Pidana Tertentu Di Indonesia. Refika Aditama.

Reksodiputro, M. (1994). Kriminologi Dan Sistem Peradilan Pidana. UI Press.

Saleh, R. (2001). Beberapa Asas-asas Hukum Pidana Dalam Perspektif (3rd ed.). Aksara Baru.

Senjata. (2021). http://id.wikipedia.org/wiki/senjata

Sianturi, E. Y. K. dan S. R. (1981). Asas Asas Hukum Pidana Dan Penerapannya. Storia Grafika.

Sidharta, M. K. \& B. A. (2000). Pengantar Ilmu Hukum Suatu Pengenalan Pertama Ruang Lingkup Berlakunya Ilmu Hukum (1st ed.). Alumni.

Simanjuntak, B. (2004). Latar Belakang Kenakalan Remaja. Alumni.

Supriadi. (2008). Etika \& Tanggung Jawab Profesi Hukum Di Indonesia. Sinar Grafika.

Weda, M. D. (2004). Mengemukakan Teori-teori Kriminologi Tentang Kejahatan. Refika Aditama.

Zahroni. (2014). Usai ujian 32 pelajar ditangkap polisi. http://www.harianterbit.com/hanterdaerah/read/Tawuran-Usai-Ujian-32Pelajar-di-Sukabumi-Diamankan-Polisi 